\title{
The Design and Construction of K11: A Novel $\alpha$-Helical Antimicrobial Peptide
}

\author{
Huang Jin-Jiang, ${ }^{1}$ Lu Jin-Chun, ${ }^{2}$ Lu Min, ${ }^{2}$ Huang Qing-Shan, ${ }^{1,2}$ and Li Guo-Dong ${ }^{2}$ \\ ${ }^{1}$ State Key Laboratory of Genetic Engineering, Institute of Genetics, College of Life Science, Fudan University, \\ Shanghai 200433, China \\ ${ }^{2}$ Shanghai Hi-Tech United Bio-Technological Research \& Development Co., Ltd, Shanghai 201206, China
}

Correspondence should be addressed to Huang Qing-Shan, qshuang@fudan.edu.cn and Li Guo-Dong, leeguod@yahoo.com.cn

Received 12 August 2011; Revised 20 October 2011; Accepted 5 December 2011

Academic Editor: Paul Cotter

Copyright (C) 2012 Huang Jin-Jiang et al. This is an open access article distributed under the Creative Commons Attribution License, which permits unrestricted use, distribution, and reproduction in any medium, provided the original work is properly cited.

Amphipathic $\alpha$-helical antimicrobial peptides comprise a class of broad-spectrum agents that are used against pathogens. We designed a series of antimicrobial peptides, CP-P (KWKSFIKKLTSKFLHLAKKF) and its derivatives, and determined their minimum inhibitory concentrations (MICs) against Pseudomonas aeruginosa, their minimum hemolytic concentrations (MHCs) for human erythrocytes, and the Therapeutic Index (MHC/MIC ratio). We selected the derivative peptide K11, which had the highest therapeutic index (320) among the tested peptides, to determine the MICs against Gram-positive and Gram-negative bacteria and 22 clinical isolates including Acinetobacter baumannii, methicillin-resistant Staphylococcus aureus, Pseudomonas aeruginosa, Staphylococcus epidermidis, and Klebsiella pneumonia. K11 exhibited low MICs (less than $10 \mu \mathrm{g} / \mathrm{mL}$ ) and broadspectrum antimicrobial activity, especially against clinically isolated drug-resistant pathogens. Therefore, these results indicate that $\mathrm{K} 11$ is a promising candidate antimicrobial peptide for further studies.

\section{Introduction}

The extensive and intensive use of antibiotics has led to the emergence of resistant strains of bacteria. During the last few years, only three new types of antibiotics have been developed for clinical use [1]. Antimicrobial peptides have been identified from a wide variety of sources, including bacteria, insects, plants, and animals [2, 3]. Most native antimicrobial peptides are effective against a broad spectrum of pathogens but can also be toxic to normal cells [4].

The intensive study of the structure and function of antimicrobial peptides has led to the development and clinical application of many peptides with enhanced activity and low toxicity; these peptides have been developed through sequence splicing, amino acid substitution, and changing the ratio of hydrophobic amino acids [5-7]. Among them, $\alpha$ helical antimicrobial peptides are one of the most studied types [8]. CP26, composed of the $\mathrm{N}$-terminal 8 amino acid residues of cecropin $\mathrm{A} 1$ and the $\mathrm{N}$-terminal 18 amino acid residues of melittin, has high antimicrobial activity and low toxicity [9]. P18, composed of 8 amino acid residues of the $\mathrm{N}$-terminus of cecropin A1 and the N-terminal 12 amino acid residues of magainin 2, showed satisfactory antimicrobial activity and no toxicity [10].

In this study, CP26 and P18 were chosen as template peptides for the synthesis of CP-P, which is composed of amino acids 1 to 11 at the N-terminus (KWKSFIKKLTS) of CP26 and amino acids 10 to 18 at the C-terminus (KFLHLAKKF) of P18. CP-P was modified to yield a number of peptides with single amino acid substitutions at different sites on the polar or nonpolar faces, and their therapeutic indices (MIC/MHC) were evaluated against Pseudomonas aeruginosa. The in vitro activities of the selected peptides with high therapeutic indices were evaluated against a set of multiresistant clinical isolates of both Gram-positive and Gram-negative pathogens. The results indicate that the modifications changed the antimicrobial activities and hemolytic toxicities. Among the derivatives, K11 exhibited a high therapeutic index and may have potential for use in further studies. 


\section{Materials and Methods}

2.1. Bacterial Strains. Twenty-two clinical isolates and night standard laboratory strains were used in this study: 4 Acinetobacter baumannii, 4 Pseudomonas aeruginosa, 3 Staphylococcus epidermidis, and 6 Klebsiella pneumonia (Changhai Hospital, Shanghai, China); 5 methicillin-resistance Staphylococcus aureus (Ruijin Hospital, Shanghai, China); Staphylococcus aureus CMCC26003; Bacillus subtilis DB430; Bacillus pumilus CMCC63202; Micrococcus luteus CMCC28001; E. coli ATCC8099; Klebsiella pneumoniae CMCC46117; Salmonella paratyphi B CMCC50094; Pseudomonas aeruginosa CMCC10104; Micrococcus S1.634. In addition, Pseudomonas aeruginosa CMCC10104 was used during the design of the peptides for evaluating antimicrobial activities. All strains were cultured on Mueller-Hinton medium.

2.2. Design of Peptides. CP-P was designed by splicing the sequences of CP26 and P18. S16, which has a single amino acid change at the 16th site of CP-P, served as a template peptide from which several peptides were derived by single amino acid substitution at different sites. All of the peptide sequences are listed in Table 1.

2.3. Synthesis and Purification of Peptides. The syntheses of the peptides CP26, P18, CP-P, S16, and the S16 derivatives (a total of 23) were carried out by solid-phase peptide synthesis (SPPS) [11]. The crude peptides were purified by RP-HPLC using a Kromasil C18-5 column at a flow rate of $1 \mathrm{~mL} / \mathrm{min}$ with a linear $\mathrm{AB}$ gradient ( $1 \%$ acetonitrile/min); mobile phase A was $0.1 \%$ trifluoroacetic in $100 \%$ water, and mobile phase B was $0.1 \%$ trifluoroacetic in $100 \%$ acetonitrile. The identities of the purified peptides were confirmed by mass spectrometry.

2.4. Circular Dichroism (CD). CD spectra were obtained with a Jasco J-710 instrument (Jasco, Tokyo, Japan) utilizing quartz cells with a $2 \mathrm{~mm}$ path length and peptide concentrations of $100 \mu \mathrm{M}$ in a $10 \mathrm{mM}$ sodium phosphate buffer with a pH of 7.5 containing $50 \%$ trifluoroethanol. Each spectrum was obtained from an average of 5 pairs of duplicates, and the percentage helicity of each peptide was determined [12].

2.5. Measurement of the Antibacterial Activity. The antibacterial activities of the different peptides were evaluated using the minimum inhibitory concentration (MIC). The process followed the standard microtiter dilution method in LB medium without salt. Briefly, bacteria were grown overnight in $\mathrm{LB}$ at $37^{\circ} \mathrm{C}$ and diluted in the same medium. Then, $100 \mu \mathrm{L}$ of the medium was dispensed into each well of a 96-well plate. The number of bacteria was between $10^{4}$ and $10^{5} \mathrm{CFU} / \mathrm{mL}$. Serial dilutions of peptides were performed consecutively in each well in $10 \mu \mathrm{L}$. Plates were incubated at $37^{\circ} \mathrm{C}$ for $24 \mathrm{~h}$; then, the $\mathrm{OD}_{620}$ was measured to determine the MIC of each peptide [13].

2.6. Measurement of Hemolytic Activity (MHC). The MHCs were measured by the method as described in Chen et
KWKSFIKKLTSKFLHLAKKF

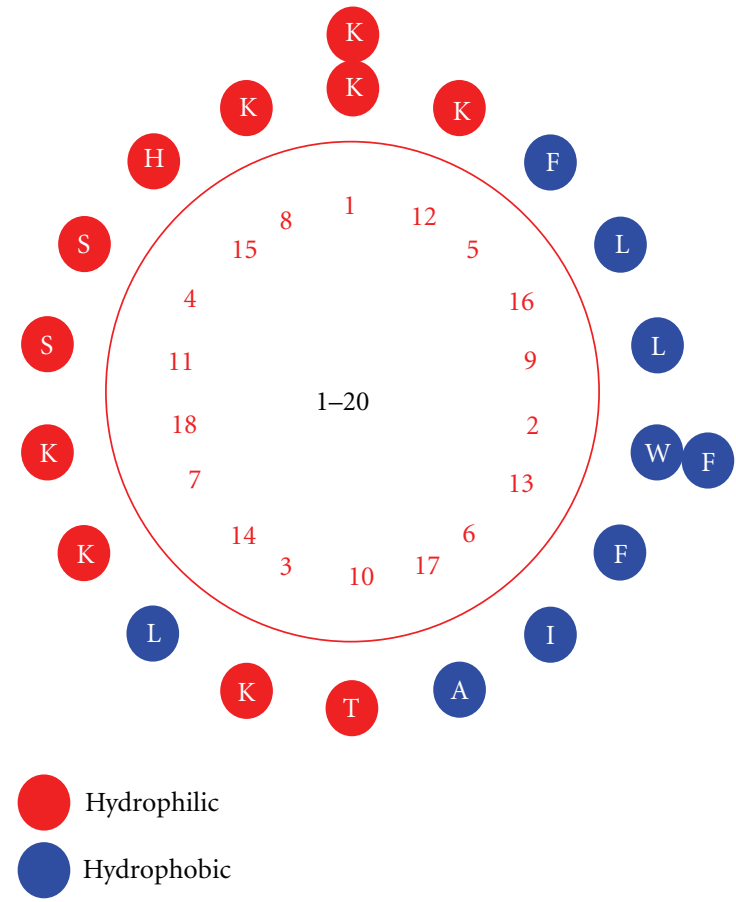

FIgUre 1: Helical wheel structure and sequence of peptide CP-P.

al. [7]: peptides were added to $1 \%$ human erythrocytes in phosphate-buffered saline $(0.08 \mathrm{~mol} / \mathrm{L} \mathrm{NaCl}, 0.043 \mathrm{~mol} / \mathrm{L}$ $\left.\mathrm{Na}_{2} \mathrm{HPO}_{4}, 0.011 \mathrm{~mol} / \mathrm{L} \mathrm{KH} \mathrm{KO}_{4}\right)$ and then kept at $37^{\circ} \mathrm{C}$ for $1 \mathrm{~h}$ in microtiter plates. The supernatants were collected by centrifugation $(800 \mathrm{~g})$, and the $\mathrm{OD}_{562}$ of each supernatant was determined. We chose a $0.1 \%$ Triton X-100 solution as the positive control because this solution causes the total release of hemoglobin. We defined the MHC as the highest peptide concentration that caused no detectable release of hemoglobin (the ratio of the $\mathrm{OD}_{562}$ for the peptide solution to the $\mathrm{OD}_{562}$ for the positive control should be less than $1 \%$ ).

\section{Results}

3.1. Design and Construction of Peptides. All of the peptides were designed based on a CP-P template, which had a higher therapeutic index than P18 and P26. S16, a derivative of CP-P with only one amino acid substitution at the 16 th site, exhibited an 8-fold on the therapeutic index. This result indicates that a polar amino acid substitution on the nonpolar face could decrease the amphipathicity and influence the antimicrobial activity to some extent. Figure 1 [14] shows the helical wheel structure of CP-P, which illustrates the polar and non-polar faces of CP-P clearly. We chose specific sites for single amino acid substitutions, constructed a series of peptides and then calculated the therapeutic index of all of the derivatives.

3.2. The Purification and Determination of the Molecular Confirmation of the Peptides. After purification, the designed 
Table 1: Peptide sequences.

\begin{tabular}{|c|c|c|c|}
\hline Peptide & Sequence & MW $(\text { Calc })^{\mathrm{a}}$ & MW (Deter) ${ }^{\mathrm{b}}$ \\
\hline CP26 & KWKSFIKKLTSAAKKVVTTAKPLISS-NH ${ }_{2}$ & 2859.7 & 2860.5 \\
\hline P18 & KWKLFKKIPKFLHLAKKF-NH ${ }_{2}$ & 2299.4 & 2300.5 \\
\hline $\mathrm{CP}-\mathrm{P}$ & KWKSFIKKLTSKFLHLAKKF-NH ${ }_{2}$ & 2480.1 & 2479.1 \\
\hline S16 & KWKSFIKKLTSKFLHSAKKF-NH ${ }_{2}$ & 2453 & 2452.1 \\
\hline F2 & KFKSFIKKLTSKFLHSAKKF-NH ${ }_{2}$ & 2415 & 2414.1 \\
\hline N3 & KWNSFIKKLTSKFLHSAKKF-NH ${ }_{2}$ & 2439.9 & 2439.1 \\
\hline K6 & KWKSFKKKLTSKFLHSAKKF- $\mathrm{NH}_{2}$ & 2469 & 2468.1 \\
\hline N7 & KWKSFINKLTSKFLHSAKKF-NH ${ }_{2}$ & 2439.9 & 2438.9 \\
\hline A9 & KWKSFIKKAKTSFLHSAKKF- $\mathrm{NH}_{2}$ & 2411.9 & 2410.7 \\
\hline K9 & KWKSFIKKKTSKFLHSAKKF-NH ${ }_{2}$ & 2469 & 2468.1 \\
\hline S9 & KWKSFIKKSTSKFLHSAKKF-NH ${ }_{2}$ & 2427.9 & 2426.7 \\
\hline R9 & KWKSFIKKRTSKFLHSAKKF-NH ${ }_{2}$ & 2497 & 2496.1 \\
\hline A10 & KWKSFIKKLASKFLHSAKKF-NH ${ }_{2}$ & 2424 & 2424.1 \\
\hline L10 & KWKSFIKKLLSKFLHSAKKF-NH ${ }_{2}$ & 2466 & 2465.1 \\
\hline D11 & KWKSFIKKLTDKFLHSAKKF-NH ${ }_{2}$ & 2482 & 2481.7 \\
\hline K11 & KWKSFIKKLTKKFLHSAKKF-NH ${ }_{2}$ & 2495.1 & 2494.4 \\
\hline L11 & KWKSFIKKLTLKFLHSKKKF-NH ${ }_{2}$ & 2480.1 & 2479.2 \\
\hline A13 & KWKSFIKKLTSKALHSAKKF-NH ${ }_{2}$ & 2377.9 & 2378.1 \\
\hline K13 & KWKSFIKKLTSKKLHSAKKF-NH ${ }_{2}$ & 2435 & 2434.3 \\
\hline K17 & KWKSFIKKLTSKFLHSKKKF-NH ${ }_{2}$ & 2511.1 & 2510.2 \\
\hline D18 & KWKSFIKKLTSKFLHSADKF-NH ${ }_{2}$ & 2440.9 & 2440.2 \\
\hline N18 & KWKSFIKKLTSKFLHSANKF-NH ${ }_{2}$ & 2439.9 & 2440 \\
\hline N20 & KWKSFIKKLTSKFLHSAKKN-NH ${ }_{2}$ & 2420.9 & 2419.6 \\
\hline
\end{tabular}

${ }^{a}$ Calculated using BioPerl.

${ }^{\mathrm{b}}$ Determined using mass spectrometry.

TABLe 2: The MICs, MHCs, and therapeutic indices of the designed peptides.

\begin{tabular}{|c|c|c|c|c|c|c|c|}
\hline Peptide & $\operatorname{MIC}(\mu \mathrm{g} / \mathrm{mL})$ & $\operatorname{MHC}(\mu \mathrm{g} / \mathrm{mL})$ & Therapeutic index & Hydrophobicity & Hydrophobic moment & $\%$ Helix & Net charge \\
\hline P18 & 25 & 250 & 10 & 0.486 & 0.405 & $\mathrm{~N}$ & 7 \\
\hline CP-P & 12.5 & 250 & 20 & 0.411 & 0.648 & 63.2 & 7 \\
\hline S16 & 3.125 & $>500$ & 160 & 0.323 & 0.596 & 71.8 & 7 \\
\hline F2 & 12.5 & 250 & 20 & 0.3 & 0.574 & $\mathrm{~N}$ & 7 \\
\hline N3 & 12.5 & $\mathrm{~N}$ & $\mathrm{~N}$ & 0.343 & 0.599 & 72.5 & 6 \\
\hline K6 & 12.5 & $\mathrm{~N}$ & $\mathrm{~N}$ & 0.184 & 0.471 & $\mathrm{~N}$ & 8 \\
\hline N7 & 12.5 & $>500$ & 40 & 0.343 & 0.586 & 72.1 & 6 \\
\hline K9 & $>50$ & $\mathrm{~N}$ & $\mathrm{~N}$ & 0.189 & 0.495 & 51.5 & 8 \\
\hline S9 & 50 & $>500$ & 10 & 0.236 & 0.529 & 68.2 & 7 \\
\hline R9 & $>50$ & $\mathrm{~N}$ & $\mathrm{~N}$ & 0.188 & 0.494 & $\mathrm{~N}$ & 8 \\
\hline A9 & 25 & $>500$ & 20 & 0.254 & 0.496 & 64.6 & 7 \\
\hline L10 & 12.5 & $<125$ & 10 & 0.395 & 0.632 & 72.1 & 7 \\
\hline A 10 & 12.5 & 250 & 20 & 0.326 & 0.597 & 72.5 & 7 \\
\hline D11 & 25 & $>500$ & 20 & 0.287 & 0.631 & 71.6 & 6 \\
\hline K11 & 1.6 & $>500$ & 320 & 0.276 & 0.642 & 67.4 & 8 \\
\hline L11 & $>50$ & $\mathrm{~N}$ & $\mathrm{~N}$ & 0.411 & 0.513 & $\mathrm{~N}$ & 7 \\
\hline A13 & 6.25 & $>500$ & 80 & 0.249 & 0.522 & 45.9 & 7 \\
\hline K13 & $>50$ & $\mathrm{~N}$ & $\mathrm{~N}$ & 0.184 & 0.457 & 62.6 & 8 \\
\hline K17 & 12.5 & $>500$ & 40 & 0.258 & 0.551 & 58.7 & 8 \\
\hline D18 & 25 & $>500$ & 20 & 0.343 & 0.587 & 51.4 & 5 \\
\hline N18 & 6.25 & $>500$ & 80 & 0.343 & 0.58 & 37.2 & 6 \\
\hline N20 & 6.25 & $>500$ & 80 & 0.204 & 0.483 & $\mathrm{~N}$ & 7 \\
\hline
\end{tabular}

Note: " $N$ " signifies that the data were not determined. 


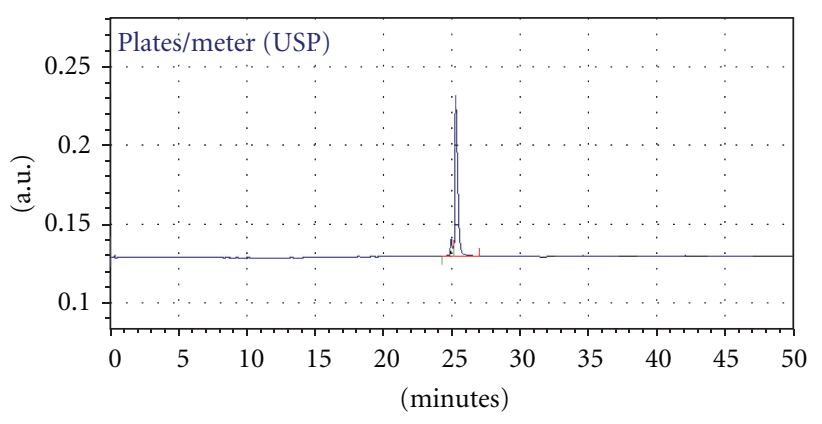

Det. 166

\begin{tabular}{lcccc}
\hline $\begin{array}{l}\text { Det. } 166 \\
\text { Results }\end{array}$ & & & & \\
\hline Time & Area & Area (\%) & Height & Height (\%) \\
24.733 & 118475 & 7.74 & 10654 & 9.46 \\
25.067 & 1412627 & 92.26 & 101914 & 90.54 \\
Totals & 1531102 & 100.00 & 112568 & 100.00 \\
\hline
\end{tabular}

FIgURE 2: Analysis of the purity of peptide S16 by HPLC

TABle 3: MIC tests on four strains of clinical Acinetobacter baumannii isolates.

\begin{tabular}{lcccc}
\hline \multirow{2}{*}{ Peptide } & \multicolumn{4}{c}{ MIC $(\mu \mathrm{g} / \mathrm{mL})$} \\
& b-01 & b-02 & b-03 & b-04 \\
\hline P18 & 6.25 & 25 & 12.5 & 12.5 \\
S16 & 3.125 & 6.25 & 6.25 & 3.125 \\
K11 & 0.8 & 3.125 & 3.25 & 1.6 \\
\hline
\end{tabular}

peptides were analyzed by RP-HPLC, which showed that their purities were greater than $90 \%$. Figure 2 shows that peptide $\mathrm{S} 16$ reached a purity of $92.3 \%$ after purification. The S16 peak was collected and analyzed by mass spectrometry. Table 1 shows that the mass spectrometry results of the synthetic peptides matched well with those calculated by BioPerl [15].

3.3. Evaluation of the Designed Peptides. After the mutation of the 16th site to serine (S16), the MIC decreased to $1 / 4$ of that of CP-P (Table 2). Table 2 also provides information about other peptides that are based on modifications of S16 by amino acid substitutions. Among these 21 peptides, peptide K11 showed the highest efficacy, with an MIC of $1.6 \mu \mathrm{g} / \mathrm{mL}$, an MHC of more than $500 \mu \mathrm{g} / \mathrm{mL}$ and a therapeutic index of 320 .

The hydrophobic moments were determined with the HeliQuest web server [16], which can be used to evaluate amphipathicity. The percent helix values were determined based on CD spectra.

3.4. Antimicrobial Activity Against Clinical Acinetobacter Baumannii Isolates. After comparison, three designed peptides, S16, K11, and P18, were chosen to use in MIC tests on four strains of clinically isolated Acinetobacter baumannii. Table 3 illustrates that peptide K11 had the lowest MICs
TABLE 4: MICs of peptide K11 for different bacteria.

\begin{tabular}{|c|c|c|}
\hline & Bacteria & $\operatorname{MIC}(\mu \mathrm{g} / \mathrm{mL})$ \\
\hline \multirow{5}{*}{ Gram-positive bacteria } & $\begin{array}{l}\text { Staphylococcus aureus } \\
\text { CMCC } 26003\end{array}$ & 0.5 \\
\hline & $\begin{array}{l}\text { Bacillus subtilis } \\
\text { DB430 }\end{array}$ & 2 \\
\hline & $\begin{array}{l}\text { Bacillus pumilus } \\
\text { CMCC63202 }\end{array}$ & 0.5 \\
\hline & $\begin{array}{l}\text { Soluble wall Micrococcus } \\
\text { S1.634 }\end{array}$ & 1 \\
\hline & $\begin{array}{l}\text { Micrococcus luteus } \\
\text { CMCC } 28001\end{array}$ & 2 \\
\hline \multirow{4}{*}{ Gram-negative bacteria } & $\begin{array}{l}\text { E. coli } \\
\text { ATCC8099 }\end{array}$ & 0.5 \\
\hline & $\begin{array}{l}\text { Klebsiella pneumoniae } \\
\text { CMCC } 46117\end{array}$ & 2 \\
\hline & $\begin{array}{l}\text { Salmonella paratyphi B } \\
\text { CMCC } 50094\end{array}$ & 2 \\
\hline & $\begin{array}{l}\text { Pseudomonas aeruginosa } \\
\text { CMCC } 10104\end{array}$ & 4 \\
\hline
\end{tabular}

TABLE 5: MICs of K11 for clinically isolated bacteria.

\begin{tabular}{lc}
\hline Bacteria & $\mathrm{MIC}(\mu \mathrm{g} / \mathrm{mL})$ \\
\hline MRSA (5) & $0.25-4$ \\
Pseudomonas aeruginosa (4) & $1.0-8.0$ \\
Staphylococcus epidermidis (3) & $0.5-8$ \\
Klebsiella pneumonia (6) & $0.5-4.0$ \\
\hline
\end{tabular}

for the four strains of Acinetobacter baumannii; these MICs were between 0.8 and $3.25 \mu \mathrm{g} / \mathrm{mL}$. Upon consideration of this result, we evaluated the antimicrobial activity of K11 against clinical isolates of both Gram-positive and Gram-negative pathogens.

3.5. Antimicrobial Activity of Peptide K11 Against Different Bacteria. Similar to the results above, peptide K11 had a lower MIC than the other designed peptides. Table 4 shows the MICs of K11 against different bacteria, revealing that K11 exhibited broad-spectrum antimicrobial activity.

3.6. Antimicrobial Activities of Peptide K11 Against Clinical Isolates. The results of MIC tests on different clinical bacterial isolates can be found in Table 5. The clinically isolated bacteria included 5 strains of MRSA, 4 strains of Pseudomonas aeruginosa, 3 strains of Staphylococcus epidermidis and 6 strains of Klebsiella pneumonia. Peptide K11 exhibited a low MIC for almost all of the strains of bacteria, which indicated that this peptide has a high antimicrobial activity against several clinically isolated drug-resistant bacteria.

\section{Discussion}

To design novel antimicrobial peptides with enhanced biological properties, we searched native antimicrobial peptides 
and selected CP26 and P18 as frameworks. CP26 and P18 have been reported to be two $\alpha$-helical peptides with high antimicrobial activities. Starting with CP26 and P18, we designed and constructed a dozen novel peptides by sequence splicing and amino acid substitution. Several of these peptides had lower MICs and higher therapeutic indices than CP26 and P18. Among them, K11 showed the maximum antimicrobial activity and minimum eukaryotic cell toxicity, with an MIC $1 / 16$ of that of P18 and a 32 -fold higher therapeutic index than P18.

Recent studies on $\alpha$-helical antimicrobial peptides have revealed that the amphipathic structure plays a primary role in the antimicrobial activity of these compounds. The reduction of antimicrobial activity resulting from the enhanced ability of self-aggregation caused by increasing amphipathicity has been reported [17]. The mechanism responsible for this effect may be the reduction of the effective molecular number after self-aggregation. In our study, we used HeliQuest to calculate the hydrophobic moment of peptides to evaluate the amphipathicity and came to the conclusion that high amphipathicity reduced the therapeutic index. S16 has a lower hydrophobic moment than CP-P (0.596 to 0.648) and was found to have a higher therapeutic index (160 to 20). Peptides L10 and D11 have high hydrophobic moments $(0.632$ and 0.631 , resp.) and exhibited low therapeutic indices $(<20)$. The MICs increased from $3.125 \mu \mathrm{g} / \mathrm{mL}$ for $\mathrm{S} 16$ to $12.5 \mu \mathrm{g} / \mathrm{mL}$ and $25 \mu \mathrm{g} / \mathrm{mL}$, and the MHCs decreased from $>500 \mu \mathrm{g} / \mathrm{mL}$ for S16 to $<125 \mu \mathrm{g} / \mathrm{mL}$. These results confirm the conclusion above, but high hydrophobic moments may also lead to increased antibacterial activities and decreased hemolytic activities. The results agree with the results of other studies that there is a threshold hydrophobicity at which optimal antimicrobial activity can be achieved [18]. In this study, K11 reached a therapeutic index of 320 and has a high hydrophobic moment (0.642).

We found that substitutions at certain specific sites $(9,11$, and 13 from the $\mathrm{N}$-terminus) can change the antimicrobial activity of S16 more effectively. The 9th residue of S16 is L, which is on the nonpolar face. If a polar amino acid were substituted at this site, there could be an increase in the MIC. R9, S9, and K9 are three derivatives that showed high MICs $(>50 \mu \mathrm{g} / \mathrm{mL})$ and decreased hydrophobic moments $(0.494$, 0.529 , and 0.495 , resp.). The substitutions at the 11th and 13th sites with opposite polar amino acids can also lead to significant increases in the MIC and decreases in the amphipathicity. We think that this structural implication should be investigated more closely in future studies.

The net positive charge on the polar face is important for the antimicrobial and hemolytic activities of antimicrobial peptides [19]. We constructed K11 by changing S to K at position 11 on the polar face of S16. This one addition to the net charge resulted in K11 showing the best biological properties among the tested peptides.

In conclusion, our results showed that the therapeutic index of a peptide depends on several factors. Modification of specific sites can change the amphipathicity to different extents, which can be used to predict the antimicrobial activity. In our study, we found a highly effective peptide,
S16, and used it as template to establish a series of peptides with single amino acid substitutions. Among these peptides, K11 showed strong therapeutic action against antibioticresistant clinical isolates of both Gram-positive and Gramnegative bacteria, making it a promising antimicrobial peptide candidate for further study, especially in vivo studies and clinical tests.

\section{Acknowledgments}

This work was supported by the Yangtze River Delta Joint Scientific and Technological Project (no. 10495810600) and the special fund of the Jiangsu Province for technological commercialization (no. BA2010089). The authors thank Professor S. U. Deming for reading this paper and W. U. Hong-yu for technical assistance.

\section{References}

[1] A. K. Marr, W. J. Gooderham, and R. E. Hancock, "Antibacterial peptides for therapeutic use: obstacles and realistic outlook," Current Opinion in Pharmacology, vol. 6, no. 5, pp. 468-472, 2006.

[2] T. Ganz and R. I. Lehrer, "Antimicrobial peptides of vertebrates," Current Opinion in Immunology, vol. 10, no. 1, pp. 4144, 1998.

[3] M. Zasloff, "Antimicrobial peptides of multicellular organisms," Nature, vol. 415, no. 6870, pp. 389-395, 2002.

[4] I. Ginsburg and E. Koren, "Are cationic antimicrobial peptides also 'double-edged swords," Expert Review of Anti-Infective Therapy, vol. 6, no. 4, pp. 453-462, 2008.

[5] S. Y. Shin, S. H. Lee, S. T. Yang et al., "Antibacterial, antitumor and hemolytic activities of $\alpha$-helical antibiotic peptide, P18 and its analogs," Journal of Peptide Research, vol. 58, no. 6, pp. 504-514, 2001.

[6] H. Sato and J. B. Feix, "Lysine-enriched cecropin-mellitin antimicrobial peptides with enhanced selectivity," Antimicrobial Agents and Chemotherapy, vol. 52, no. 12, pp. 4463-4465, 2008.

[7] Y. Chen, C. T. Mant, S. W. Farmer, R. E. W. Hancock, M. L. Vasil, and R. S. Hodges, "Rational design of $\alpha$ helical antimicrobial peptides with enhanced activities and specificity/therapeutic index," Journal of Biological Chemistry, vol. 280, no. 13, pp. 12316-12329, 2005.

[8] A. Giangaspero, L. Sandri, and A. Tossi, "Amphipathic $\alpha$ helical antimicrobial peptides," European Journal of Biochemistry, vol. 268, no. 21, pp. 5589-5600, 2001.

[9] M. G. Scott, H. Yan, and R. E. W. Hancock, "Biological properties of structurally related $\alpha$-helical cationic antimicrobial peptides," Infection and Immunity, vol. 67, no. 4, pp. 20052009, 1999.

[10] S. Y. Shin, M. K. Lee, K. L. Kim, and K. S. Hahm, "Structureantitumor and hemolytic activity relationships of synthetic peptides derived from cecropin A-magainin 2 and cecropin Amelittin hybrid peptides," Journal of Peptide Research, vol. 50, no. 4, pp. 279-285, 1997.

[11] J. D. Fontenot, J. M. Ball, M. A. Miller, C. M. David, and R. C. Montelaro, "A survey of potential problems and quality control in peptide synthesis by the fluorenylmethoxycarbonyl procedure," Peptide Research, vol. 4, no. 1, pp. 19-25, 1991. 
[12] U. Pag, M. Oedenkoven, V. Sass et al., "Analysis of in vitro activities and modes of action of synthetic antimicrobial peptides derived from an $\alpha$-helical 'sequence template," Journal of Antimicrobial Chemotherapy, vol. 61, no. 2, pp. 341-352, 2008.

[13] I. Y. Park, C. B. Park, M. S. Kim, and S. C. Kim, "Parasin I, an antimicrobial peptide derived from histone $\mathrm{H} 2 \mathrm{~A}$ in the catfish, Parasilurus asotus," FEBS Letters, vol. 437, no. 3, pp. 258-262, 1998.

[14] G. Deléage, C. Combet, C. Blanchet, and C. Geourjon, "ANTHEPROT: an integrated protein sequence analysis software with client/server capabilities," Computers in Biology and Medicine, vol. 31, no. 4, pp. 259-267, 2001.

[15] J. E. Stajich, D. Block, K. Boulez et al., "The Bioperl toolkit: Perl modules for the life sciences," Genome Research, vol. 12, no. 10, pp. 1611-1618, 2002.

[16] R. Gautier, D. Douguet, B. Antonny, and G. Drin, "HELIQUEST: a web server to screen sequences with specific $\alpha$-helical properties," Bioinformatics, vol. 24, no. 18, pp. 2101-2102, 2008.

[17] Y. Chen, M. T. Guarnieri, A. I. Vasil, M. L. Vasil, C. T. Mant, and R. S. Hodges, "Role of peptide hydrophobicity in the mechanism of action of $\alpha$-helical antimicrobial peptides," Antimicrobial Agents and Chemotherapy, vol. 51, no. 4, pp. 1398-1406, 2007.

[18] Z. Jiang, A. I. Vasil, L. Gera, M. L. Vasil, and R. S. Hodges, "Rational design of $\alpha$-helical antimicrobial peptides to target Gram-negative pathogens, Acinetobacter baumannii and Pseudomonas aeruginosa: utilization of charge, "specificity determinants," total hydrophobicity, hydrophobe type and location as design parameters to improve the therapeutic ratio," Chemical Biology and Drug Design, vol. 77, no. 4, pp. 225-240, 2011.

[19] Z. Jiang, A. I. Vasil, J. D. Hale, R. E. W. Hancock, M. L. Vasil, and R. S. Hodges, "Effects of net charge and the number of positively charged residues on the biological activity of amphipathic $\alpha$-helical cationic antimicrobial peptides," Biopolymers, vol. 90, no. 3, pp. 369-383, 2008. 

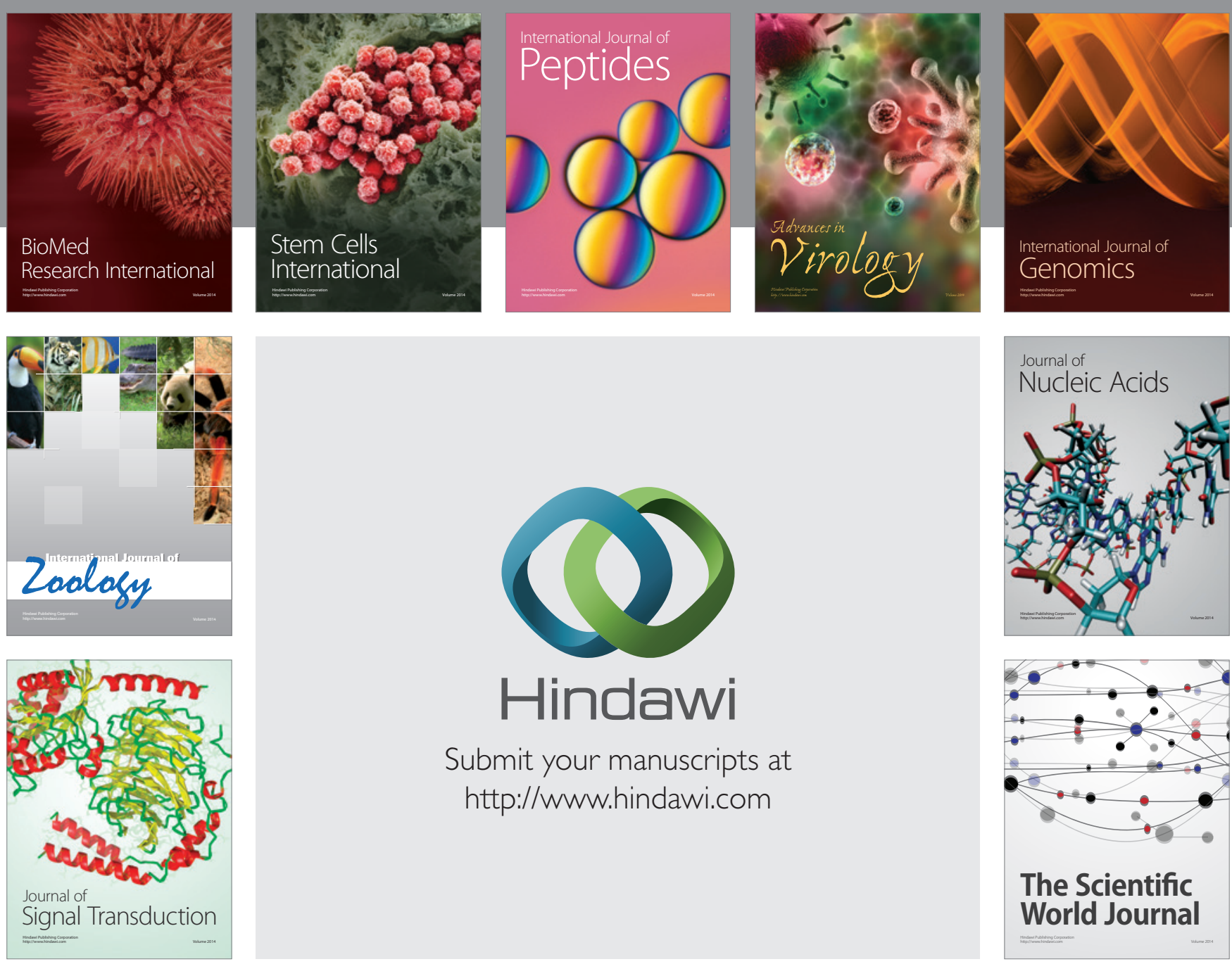

Submit your manuscripts at

http://www.hindawi.com
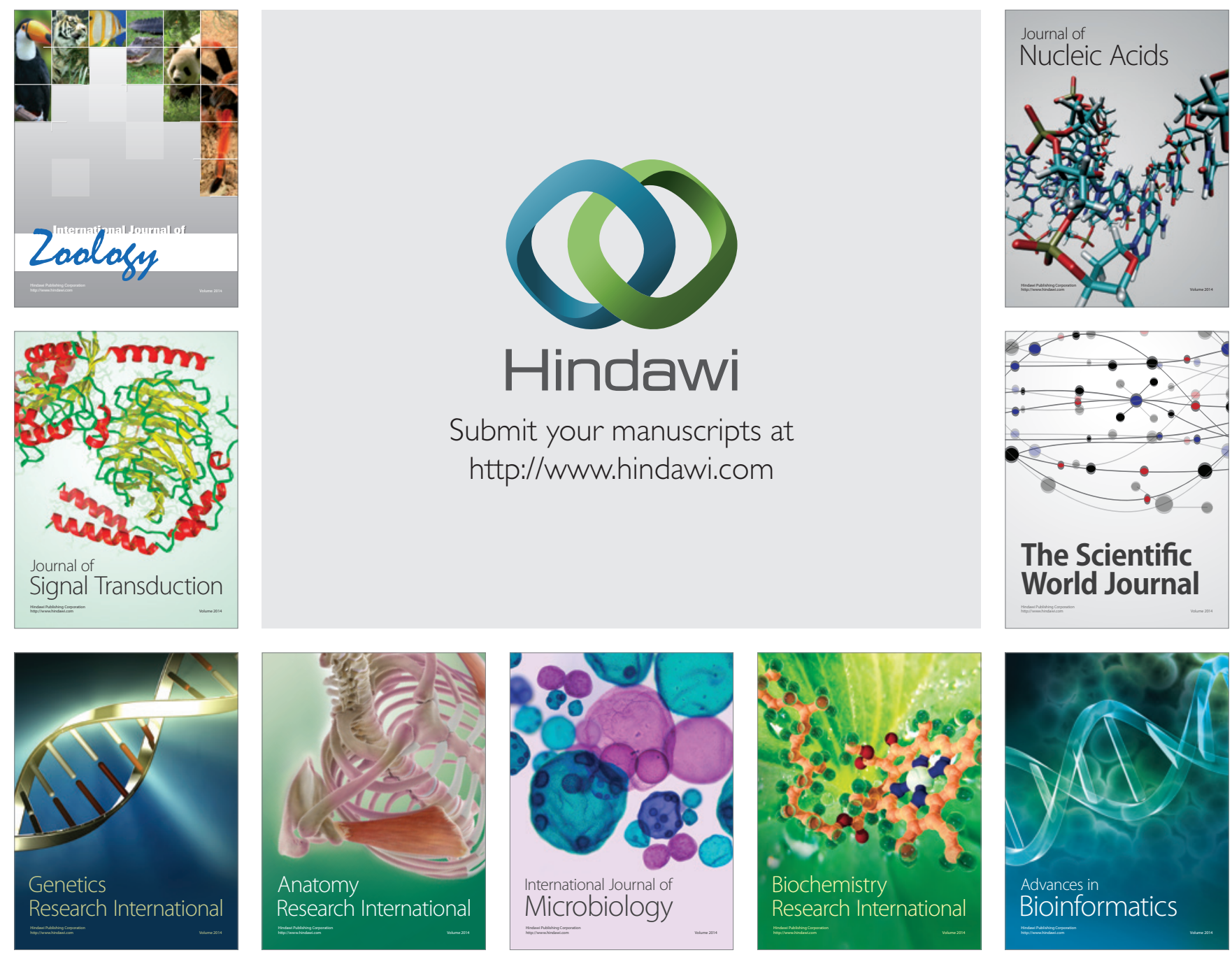

The Scientific World Journal
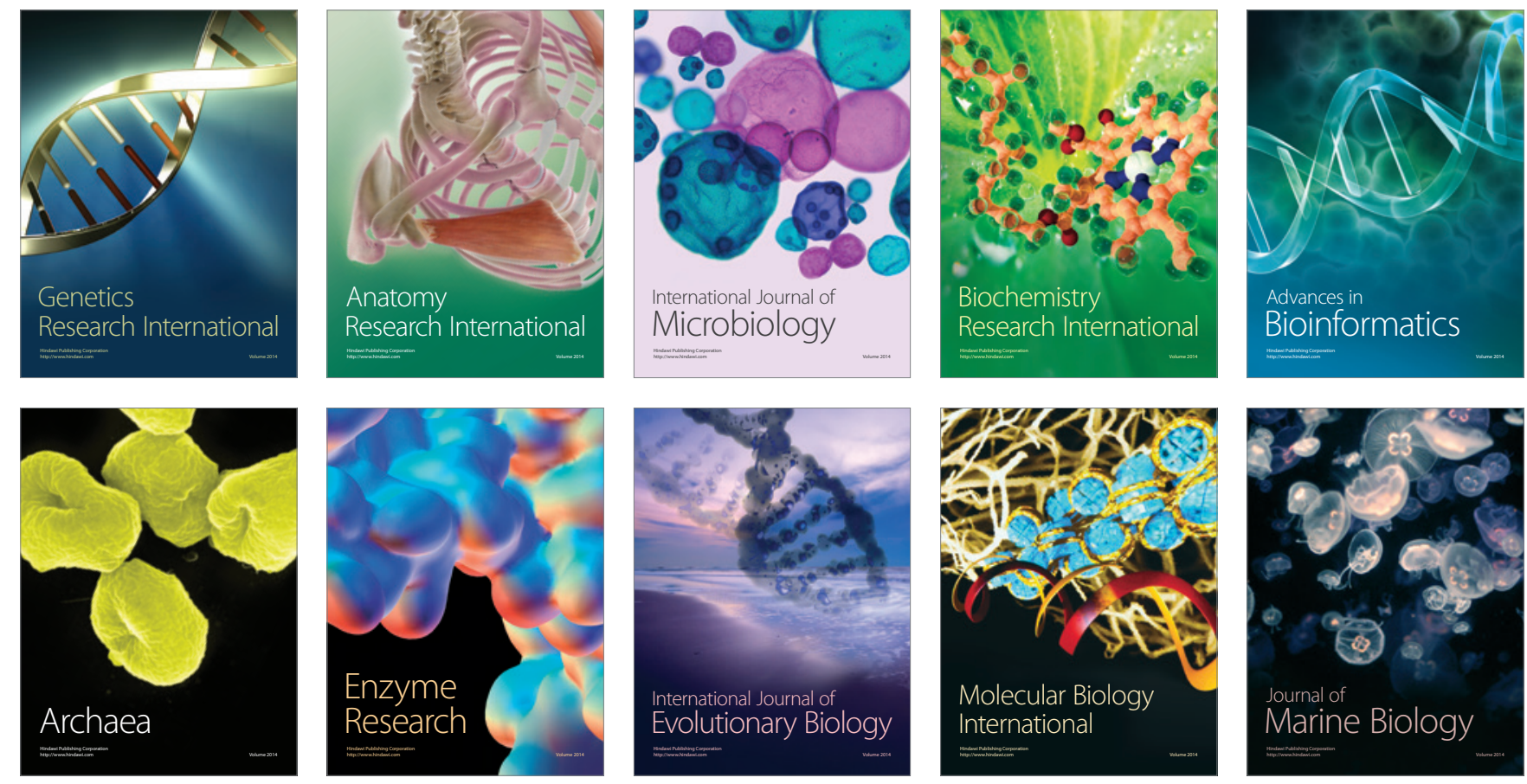